\title{
Diploid and triploid Pacific oysters, Crassostrea gigas (Thunberg), reared at two heights above sediment in Marennes-Oleron Basin, France: Difference in mortality, sexual maturation and hemocyte parameters
}

\author{
Gagnaire Beatrice ${ }^{1}$, Soletchnik Patrick ${ }^{2}$, Madec Patrick ${ }^{2}$, Geairon Philippe ${ }^{2}$, Le Moine Olivier ${ }^{2}$ \\ and Renault Tristan ${ }^{1^{*}}$ \\ ${ }^{1}$ IFREMER, Laboratoire de Génétique et Pathologie (LGP), 17390 La Tremblade \\ ${ }^{2}$ IFREMER, Laboratoire Environnement et Ressources des Pertuis-Charentais (LERPC), 17390 La Tremblade
}

*Corresponding author: Tristan Renault, IFREMER, LGP, 17390 La Tremblade, Tel: 335463698 36, Fax: 335463637 51, E-mail: trenault@ifremer.fr

\begin{abstract}
:
Summer mortality is an important economic concern for the Pacific oyster, Crassostrea gigas, industry all over the world and particularly in France. Outbreaks appear when oysters are in gonadal maturation. Bivalve defence mechanisms against pathogen invasion are assumed by circulating cells, the hemocytes. A field experiment was conducted in the Marennes-Oleron Basin (Charente-Maritime, France) in order to monitor hemocyte parameters, gametogenesis and mortality rates among $C$. gigas during 7 months from March to September 2002. Diploid (from natural bed and from hatchery) and triploid oysters were placed at $15 \mathrm{~cm}$ or $70 \mathrm{~cm}$ above sediment at Marennes-Oleron Basin. Triploid animals were included because they are considered as sterile animals. Mortality rates were monitored and lipid contents were analysed in order to define sexual maturation stages. Hemocyte parameters (cell mortality, enzymatic activities and phagocytosis) for the three oyster groups were monitored by flow cytometry. Results were analysed by pooling data for the whole sampling period and by separating data in three periods related to the gametogenesis process (A, B and C). Mortality outbreak occurred during the ripe gamete period (B). Results showed that triploids presented the highest values for several hemocyte parameters and the lowest mortality rates. Differences between triploids and diploids were highest during the ripe gamete period. Relationships between oyster mortality, gonadal maturation and hemocyte parameters are discussed. This is the first study monitoring hemocyte parameters of wild diploid, hatchery bred diploid and triploid oysters reared in the field.
\end{abstract}

Keywords: Pacific oyster; Crassostrea gigas; Hemocyte activities; Flow cytometry; Diploids; Triploids; Summer mortality; Sexual maturation 


\section{Introduction}

Important mortality outbreaks have been reported in Crassostrea gigas populations since the 1940s in Japan in different locations (Koganezawa, 1974), on the west coast of North America (Glude, 1974; Cheney et al., 2000), and on the French coasts since 15 years (Renault et al., 1994; Goulletquer et al., 1998; Soletchnik et al., 1999). The syndrome is known as summer mortality. As worldwide bivalve production is mainly based on the Pacific oyster, summer mortality appears as a major concern for the shellfish industry (Mori, 1979; Perdue et al., 1981; Beattie, 1988). Factors such as food limitation, oxygen depletion, salinity and temperature do not appear as single direct causes of the syndrome (Soletchnik et al., 1998). Moreover, outbreaks occur during oyster gametogenesis. Some authors suggest that mortalities occurring in Pacific oysters are the result of multiple factors, including elevated temperatures, physiological stress associated with gonadal maturation, aquaculture practices, pathogens, and pollutants (Goulletquer et al., 1998). Therefore, it can be assumed that the background rate of mortality due to environmental conditions, and the physiological and genetic origin of the oysters, can be modified by infectious agents. As many filter-feeding benthic invertebrates, oysters are permanently exposed to various micro-organisms. Efficient humoral and cellular defence mechanisms normally help to limit the proliferation of micro-organisms in animals (Harris-Young et al., 1995; Cheng, 1996). Stress and disease outbreaks appear to be linked in molluscs (Friedman et al., 1999; Lacoste et al., 2001b). In vitro investigations reveal that noradrenaline, the main catecholamine released in oyster hemolymph during stress exerts an inhibitory effect on immune functions such as phagocytosis and reactive oxygen species production (Lacoste et al., 2001a; Lacoste et al., 2002). As a consequence, possible relationships between environmental factors, physiological state of oysters, immune system and pathogens need further investigations.

Since 1996, summer mortality of Pacific oyster, C. gigas, has been studied in the south of MarennesOleron Bay (Charente-Maritime, France) (Lodato, 1997). Mortality of oysters reared near the sediment was significantly higher than mortality of oysters reared on racks (Soletchnik et al., 1999). Previous studies also showed allocation of energy to reproduction, and gain in shell and somatic tissue weight, to be lower near the sediment than on racks at $50 \mathrm{~cm}$ or $70 \mathrm{~cm}$ above the sea bed (Goulletquer et al., 1998; Soletchnik et al., 1999; Soletchnik et al., 2003).

The Pacific oyster, $\underline{C}$. gigas, possesses an open circulatory system (Cheng, 1981). Internal defence mechanisms of bivalves involve circulating blood cells, the hemocytes. These cells are considered to be the equivalent of vertebrate phagocytic cells because of their morphology and functions. Hemocytes are involved in the recognition of invading pathogens and in their elimination by phagocytosis and encapsulation (Cheng, 1981; Fisher, 1986). Hemocyte activities have already been used for monitoring oyster immune capacities. Moreover, hemocyte parameter values can depend on oyster physiological status including sexual maturation.

Pacific oysters, $\underline{\text { C. gigas, }}$ are among the most widely cultured of all shellfish species. To help meet demand, advantages of increased sterility are currently being exploited during commercial growing of

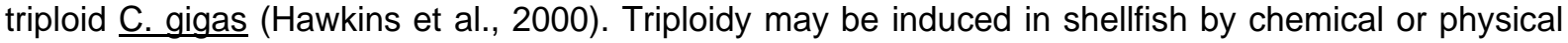
treatment which retain a polar body during early division of the egg, with the result that each cell nucleus contains one additional set of chromosomes (Beaumont, Fairbrother, 1991). Triploids can also be produced by crossing tetraploid males and diploid females (Nell, 2002). Triploidy is now widely used to obtain faster growth than diploids in shellfish. Gametogenesis is reduced in these animals. Triploid oysters invest less energy in gamete production, so more energy is available for somatic growth (Nell, 2002). Heterozygosity is higher, which could have positive influences on feeding rate, absorption efficiency and growth efficiency (Magoulas et al., 2000). Metabolic energy costs are lower than diploids, rendering triploids more resistant to stressful conditions (Garnier-Gere et al., 2002). However, difference in survival between triploids and diploids has been controversial.

As a part of a multiyear French research programme on summer mortalities in $\underline{C}$. gigas oysters called MOREST, a focal study has been conducted on diploid and triploid oysters reared at two heights above sediment in Marennes-Oleron bay (Charente-Maritime, France). Mortality rates were daily monitored and lipid contents analysed in order to define sexual maturation stages. Hemocyte parameters including granulocyte percentage, phagocytosis, percentages of cells possessing hydrolytic enzymes (esterases, peroxidases) were investigated using flow cytometry. This method appears well suited to morphological and functional characterisation of oyster hemocytes (Renault et al., 2001; Xue et al., 2001). These parameters are usually monitored in studies on bivalve hemocytes (Cheng et al., 1978; Beckmann et al., 1992; Carballal et al., 1997). Daily mortality was also monitored on all oyster groups. Lipid contents were also measured for all oyster groups and their analysis allowed to define sexual maturation status. 
In the present paper, we have analysed the possibility that environmental conditions and physiological state of the oysters may alter hemocyte functions, rendering the oysters more susceptible to infectious agents. Relationships between maturation stages and hemocyte parameters in three oyster groups (triploids, diploids from natural bed and hatchery diploids) and rearing levels above the sea bed were studied. Results were analysed firstly by pooling all data for the whole sampling period, and secondly by separating data in three periods related to the gametogenesis process. The aim of this study was to identify possible relationships between gonadal maturation, oyster group, rearing level, hemocyte parameters and oyster mortality.

\section{Material and Methods}

\subsection{Experimental set}

The three groups of oysters : diploid oysters (D), and hatchery diploid (Dh) and triploid (T) oysters. D were 2.5 year-old wild oysters from Marennes-Oleron Bay (French Atlantic coast). Dh were hatchery reared oysters from experimental hatchery of IFREMER (La Tremblade Charente Maritime, France). Triploid oysters $(T)$ were produced by crossing tetraploid males and diploid females from a private hatchery. Oysters were grown in the south of the Marennes-Oleron Bay in bags placed on tables. Oyster were reared on "off bottom" culture racks, $15 \mathrm{~cm}$ (L1) and $70 \mathrm{~cm}$ (L2) above the sea bed from March to September 2002. Sampling dates were: May 14 and 28 ; June 6, 12, 20 and 26 ; July 3, 25 ; August 8, 21 and September 11. Seawater temperature was recorded by "YSI" probe in 15-min steps from March to September 2002.

\subsection{Oyster mortality}

Oysters were deployed in mesh bags, at a starting density of 200 per bag, placed on iron racks. Live and dead oysters were counted at each sampling date in three bags per condition. Dead oysters were removed from bags. Percentage of mortality between each sampling date was afterwards transformed in daily rate by dividing per the number of days.

\subsection{Lipid content analysis}

Measurement of lipid content was carried out on the same animals used for hemocyte collection. Biochemical analysis of tissues was carried out on each batch in 3 replicated pools of 10 oysters for each level (L1 and L2) and oyster group (D, Dh and T). Lipids were extracted and purified according to a protocol previously described (Bligh, Dyer, 1959) and the analytical procedure was from Marsh and Weinstein (Marsh, Weinstein, 1966). Spectrophotometric analysis was conducted on an aliquot of ground tissues of each pool. Results are expressed in $\mathrm{mg}$ of lipids per gram of dry tissues. Dry tissues lipids have previously been shown to indicate the maturation level at the different sampling dates (Deslous-Paoli et al., 1981; Soletchnik et al., 1999; Soletchnik et al., 2002). Maturation stages refer to a relative scale previously defined corresponding to gametogenesis in progress, ripe stage and postspawning stage (Soletchnik et al., 1997).

\subsection{Circulating hemocyte collection}

After removing the shell by severing the adductor muscle, hemolymph was withdrawn directly from the pericardial cavity by puncture with a $1 \mathrm{~mL}$ syringe equipped with a needle $(0.9525 \mathrm{~mm})$. For each oyster, $0.5 \mathrm{~mL}$ of hemolymph was withdrawn without any buffer. Hemolymph samples were conserved on ice during collection to prevent hemocyte aggregation (25). For each group (TL1, DL1, DhL1, TL2, DL2 and DhL2), thirty oysters were sampled at each date. The samples were combined into three pools of 10 oysters each to reduce inter-individual variation and to provide sufficient hemocytes to fulfil assay requirements. 


\subsection{Cell analysis by flow cytometry}

Hemocytes were analysed with an EPICS XL 4 flow cytometer (Beckman Coulter) after hemocyte collection using previously described protocols (Xue et al., 2001; Auffret et al., 2002). For each hemocyte pool, 3000 events were counted. Results were depicted as cell cytograms indicating the relative size (FSC value), the granularity (SSC value) and the fluorescence channel(s) corresponded to the marker used. Presence of enzymes and phagocytosis were measured using FL1 (green fluorescence) and cell mortality using FL3 (red fluorescence).

Esterase and peroxidase activities were evaluated using commercial kits (Cell Probe ${ }^{\mathrm{TM}}$ Reagents, Beckman Coulter). Percentages of cells presenting enzymatic activities were defined on the basis of fluorescent cells among all cells. Each analysis required $200 \mu \mathrm{L}$ of hemolymph and $20 \mu \mathrm{L}$ of the corresponding kit reagent (FDA (Fluorescein Diacetate)•Esterase and DFCH (Dichlorofluorescein Diacetate), PMA (Phorbol-12-Myristate-13-Acetate)•Oxidative Burst). Hemocytes were then incubated in the dark at ambient temperature for 15 minutes for esterase and peroxidase detection. Hemocyte mortality $(\mathrm{Hm})$ was quantified using $200 \mu \mathrm{L}$ of hemolymph. Hemocytes were incubated in the dark for 30 minutes at $4{ }^{\circ} \mathrm{C}$ with $10 \mu \mathrm{L}$ of propidium iodide (PI, $1.0 \mathrm{mg} \cdot \mathrm{mL}^{-1}$, Interchim). Morphological characteristics of hemocytes were also recorded: gates were realised on the SSC/FSC plot on the most granular and largest cells in order to determine a granulocyte population. Phagocytosis was measured in vitro as the proportion of cells that had ingested three or more fluorescent beads. Two hundred $\mu \mathrm{L}$ of hemolymph were incubated for one hour in the dark at ambient temperature with $10 \mu \mathrm{L}$

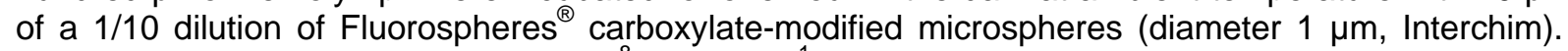
The final concentration of beads was $10^{8}$ beads. $\mathrm{mL}^{-1}$.

\subsection{Statistical analysis}

Statistical multi-way analysis of variance, Least Significant Differences (LSD) post hoc test were realised using Statgraphics version 5.1 software. Hemocyte parameters and cumulated mortalities were converted into $r$ angular arc sinus $\sqrt{ }$ (value) before analysis. However, figures were realised using non-transformed percentage values. 


\section{Results}

\subsection{Oyster mortality}

A daily mortality rate, ranging from $2 \%$ to $5 \%$, occurred in the two groups of diploid oysters at L1 level between June 21-26 (Figure 1). Daily mortality of diploid oysters did not exceed $0.5 \%$ at L2. Mortality occurred after temperature had reached $18-19^{\circ} \mathrm{C}$ for a few days. After a 7 month rearing period (March to September 2002), the highest cumulative mortality, $36.2 \%$ and $43.8 \%$, affected the DL1 and DhL1 groups, respectively (Figure 2). Significant differences were reported between L2 and L1 cumulative mortality for each oyster population: $21.5 \%$ at L2 and $36.2 \%$ at L1 for wild diploids, 14.3 $\%$ at L2 and $43.8 \%$ at L1 for hatchery diploids, and $6.5 \%$ at L2 and $11.3 \%$ at L1 for triploids (Figure 2). Whatever the rearing levels, cumulative mortality in triploid oysters was significantly lower (Figure 2).

\subsection{Lipid content and definition of maturation stages}

From March to mid May 2002, the mean lipid content was about $80-85 \mathrm{mg} \mathrm{g}^{-1}$ for diploid and triploid oysters (Figure 3). Values then reached $\sim 150 \mathrm{mg} \mathrm{g}^{-1}$ at the end of June 2002 and remained at this level until spawning for the two groups of diploid oysters (D and Dh) (Figure 3a\&b). Lipid content did not exceed $\sim 100 \mathrm{mg} \mathrm{g}^{-1}$ for triploid oysters (Figure 3c). After spawning in August 2002, lipid contents fell in diploids to $90 \mathrm{mg} \mathrm{g}^{-1}$. Three periods $\mathrm{A}, \mathrm{B}$ and $\mathrm{C}$ were defined on the basis of lipid contents in diploids. Period A was defined as the active gametogenesis (before mortality; May to June $20^{\text {th }}$ ), period B was defined as the ripe gametes period (after mortality; June $20^{\text {th }}$ to August ${ }^{\text {th }}$ ) and period $C$ was defined as the post-spawning period (August $8^{\text {th }}$ to September $11^{\text {th }}$ ) (Figure 3 ). The evolution of lipid contents was directly related to maturation stage, with a maximal value just before spawning. Values for triploid oysters remained about $100 \mathrm{mg} \mathrm{g}^{-1}$ (Figure 3c).

\subsection{Hemocyte parameters : effect of sites and oyster groups}

The first analysis was realised on the whole data, in order to study a potential difference between oyster groups or an effect of rearing level on the basis of hemocyte parameters. Two-way analysis of variance of each parameter was carried out. Thirty-three values were available for each hemocyte parameter. Results showed no effect of level $(p>0.05)$ for any of the hemocyte parameters (Figure 4 , Table 1). On the contrary, some parameters varied significantly among the three oyster groups. Phagocytosis values were significantly higher for triploids than for diploids $(p<0.0001)$ (Figure $4 a$, Table 1). For triploids, $36.7 \%$ (L1) and $29.5 \%$ (L2) of hemocytes presented phagocytosis activity. For diploids D, 21.8\% (L1) and $25.0 \%$ (L2) of hemocytes presented phagocytosis activity. For diploids Dh, $20.2 \%$ (L1) and $16.4 \%$ (L2) of hemocytes presented phagocytosis activity (Table 1). Percentages of cells presenting a peroxidase activity differentiated $T, D$, and Dh oysters ( $T>D>D h$, LSD test, $\mathrm{p}<0.0001$ ) (Figure 4c, Table 1). Percentages of cells presenting an esterase activity and the granulocyte percentage were also significantly higher for triploids than for diploids $(p<0.05)$ (Figures $1 b, 1 d$, Table 1). Cell mortality permitted differentiation between triploid and diploid groups $(T<D=D h$, Figure 4f). However, this result was not significant $(p<0.1)$.

\subsection{Relationships between hemocyte activities and gonadal maturation, oyster groups or rearing levels}

The multi-way analysis of variance of hemocyte activities versus levels (L1 and L2), oyster groups (D, Dh and T) and maturation stages (A, B and C, Figures 1 and 3) demonstrated a major effect of maturation. All the hemocyte activities showed lowest values during period $A$ compared to $B$ or $C$ periods (Table 2, $p<0.001$ ). "Oyster group" had a significant effect on phagocytosis, esterase and peroxidase activities and granulocyte percentage (Table $2, p<0.01$ ). Highest hemocyte activities were reported in triploid oysters. The rearing level had an effect only on esterase activity: values were significantly higher at L1 (Table $2, \mathrm{p}<0.05)$.

Phagocytosis values were maximal for triploid oysters during the A and B periods $(21.3 \%$ and $48.1 \%$, respectively) (Figure 5a, Table 2). Phagocytosis values for natural bed diploids were $13.1 \%$ and 24.7 $\%$ during the $\mathrm{A}$ and $\mathrm{B}$ periods and for hatchery diploids $9.0 \%$ and $22.0 \%$ during the $\mathrm{A}$ and $\mathrm{B}$ periods, respectively (Figure $5 \mathrm{a}$, Table 2). After spawning, in period $\mathrm{C}$, triploids and diploids presented similar values of phagocytosis. The highest percentages of peroxidase and esterase positive cells were recorded for triploids in period $A$ and $B$ (Figures $2 c$ and 2e, Table 2). Triploids presented the highest 
percentages of granulocytes during the three periods (A, B and C), with a maximum value $(21.7 \%)$ in period C (Figure 5b, Table 2).

Values were not statistically different between triploids and diploids for hemocyte mortality, but were lower for triploids in periods A and B (10.9\% and $13.4 \%$, Figure $5 \mathrm{~d}$, Table 2) than for hatchery diploids in period B (32. \%, Figure $5 \mathrm{~d}$, Table 2). Hatchery diploids presented the lowest activities for hemocyte parameters during period $A$ and period C: phagocytosis activity (Figure 5a, Table 2), percentage of peroxidase, esterase positive cells (Figures $2 \mathrm{c}, 2 \mathrm{e}$ and $2 \mathrm{f}$, Table 2 ), and percentage of granulocytes (Figure 5b, Table 2). Hatchery diploids also presented the lowest activities for two parameters in period B: the lowest phagocytosis activity (Figure $5 \mathrm{a}$, Table 2) and percentage of peroxidase positive cells (Figure $5 c$, Table 2 ).

\section{Discussion}

Field studies on summer mortality of $\underline{C}$. gigas have been conducted in France for several years (Lodato, 1997; Goulletquer et al., 1998; Soletchnik et al., 1999; Soletchnik et al., 2003; Soletchnik et al., 2005). A mortality model comparing "on" and "off" bottom culture has been developed (Soletchnik et al., 2005). This model demonstrated an effect of proximity to sediment on oyster survival, called "sediment effect". This result was confirmed in the present experiment. Mortality of diploid oysters from natural bed was higher at rearing level L1 $(15 \mathrm{~cm})$ than at L2 $(70 \mathrm{~cm})(36.2 \%$ cumulative mortality versus $21.5 \%$ after a six-month grow-out period). Mortality of wild diploid oysters was also nearly doubled in 1997 on the same site, with 8-19\% and 23-33\%, for L2 and L1, respectively (Soletchnik et al., 1999). Mortality rates for "off" and "on" bottom culture were $8-15 \%$ and $40-50 \%$ in 2000 and $10 \%$ and 28\% in 2001, respectively (Soletchnik et al., 1997). In 2000 and 2001, mortality outbreaks occurred in June after an increase of seawater temperature above $19^{\circ} \mathrm{C}$. Other studies conducted in USA reported mortality outbreaks during the same period (June and July) (Perdue et al., 1981; Cheney et al., 2000).

In the present study, hatchery diploids presented the highest cumulative mortality at L1. Moreover, cumulative mortality was as in wild diploids higher at L1 than at L2 (43.8 \% and $14.3 \%$, respectively). Triploids presented the lowest mortality rates, but cumulative mortality was also statistically different between L1 and L2 (11.3\% and $6.5 \%$, respectively). This is the first field study in France including diploid and triploid oysters from hatchery. In this "on-off" bottom model, the rearing level allows to explain partly mortality outbreaks: cumulative mortality was higher at L1 than at L2 for the three oyster populations. A study on the Sydney rock oyster, Saccostrea glomerata, reported a higher mortality at low height compared to high height (Smith et al., 2000).

In this study, we also measured oyster lipid contents in order to define different stages of sexual maturation. This technique has already been use before (Deslous-Paoli et al., 1981; Soletchnik et al., 1999; Soletchnik et al., 2002). Diploids presented the highest mortality rates and mortalities were observed during the ripe gamete period (B). As recorded by other authors (Imai et al., 1965; Perdue et al., 1981), mortality occured during gametogenesis. On the contrary, the lowest mortality rates were reported for triploid oysters, presenting low lipid contents. Another study on Hiroshima Bay also

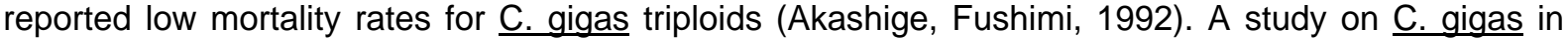
Australia also reported lower mortality of triploids compared to diploids (Nell, Perkins, 2005). Another study on the Sydney rock oyster, Saccostrea glomerata, reported a higher survival rate for triploids than diploids (Hand et al., 1998). However, on this same oyster, another study reported no difference of mortality between triploids and diploids (Smith et al., 2000). Other studies in USA always reported a mortality rate twice higher for triploids compared to diploids (Cheney et al., 1998; Cheney et al., 2000; Cheney et al., 2004).

A major aim of this study was also to monitor certain hemocyte parameters in oysters placed in the field over a long period. Our results underscore the utility of flow cytometry in monitoring hemocyte functions in oysters (Goedken, De Guise, 2004). To our knowledge this is the first study evaluating hemocyte activities in triploid oysters reared in the field. The analysis of the whole data (without separation by periods on the basis of sexual maturation) showed that triploid oysters presented statistically higher hemocyte activities than diploid oysters from hatchery and from natural bed for several parameters (phagocytosis, esterase and peroxidase activities and granulocyte percentages). When analysing the data by periods related to the gametogenesis status ( $A, B$ and $C$ ), statistically 
significant differences for the same hemocyte parameters were reported between diploids (low values) and triploids (high values). Moreover, the highest differences for esterase and phagocytosis activities were reported between animals presenting the lowest mortality (triploids) and animals presenting the highest mortality (diploids) during period B (ripe gamete period) where mortality events were reported. We can therefore hypothesize that gametogenesis process makes diploid oysters more susceptible to several factors and then lead to mortality. The principal characteristic of triploid oysters was the absence of sexual maturation during Spring and Summer 2002. During the ripe gamete period (B), triploid oysters presented no gamete development. We can assume that during the ripe gamete period B, diploid oysters allocated energy to gamete production, and on that account, a minimum of energy was allocated to the defence system. Triploids do not use energy in gamete synthesis and so may allocate energy for other processes including hemocyte activities and defence mechanisms. A previous study reported a decrease of the activity of complement and the number of lymphocytes during sexual maturation of the sockeye salmon, Oncorhynchus nerka (Alcorn et al., 2002). Sexual maturation is a sensitive period and physiological activities such as defence mechanisms can be disrupted.

Peroxidase activities allowed differentiation between diploids from hatchery and from natural bed, with lowest values for hatchery diploids $(\mathrm{Dh}<\mathrm{D})$. Moreover, esterase activity was higher at L1 level, where highest mortality were reported for both diploid populations. This difference appeared only when data for the three gonadal maturation periods (A, B and C) were analysed separately. We may assume that at L1, bacterial biomass related to turbidity is more important (Lodato, 1997). The environment at the lower level $(15 \mathrm{~cm})$ induced a greater stimulation of the immune system.

Hemocyte parameters monitored in this study allowed differentiation between oysters presenting high mortality (diploids: from $14.3 \%$ to $43.8 \%$ of cumulative mortality) and low mortality (triploids: $6.5 \%$ and $11.3 \%$ of cumulative mortality). However, only one parameter allowed differentiation between both diploid populations and only one parameter allowed to differentiate both levels, although mortality was higher at L1. As hemocyte parameters are different between triploids and diploids, we can hypothesize that abnormal mortalities account for more than $12 \%$ of cumulative mortality. Beyond this threshold, oysters presenting different percentages of cumulative mortality can not be differentiated on the basis of the hemocyte parameters monitored. We can therefore hypothesize that only abnormal mortality, and not genetic origin or rearing level, explains values obtained for hemocyte parameters.

However, the factors implicated in C. gigas mortality are not identified yet. Some authors hypothesised the impact of physico-chemical factors in seawater (Cheney et al., 2000), toxicity of sediment, presence of pollutants, the role of bacterial infections (Lacoste et al., 2001b; Le Roux et al., 2002; Waechter et al., 2002), and herpesviral infections following temperature elevation (Renault et al., 1994; Renault et al., 1995). However, no difference has been found in the resistance of triploid or diploid C. virginica (Gmelin) oysters to infection by MSX (Haplosporidium nelsoni) or Perkinsus marinus (Meyers et al., 1991; Barber, Mann, 1991; Matthiessen, Davis, 1992). Further experiments should be conducted in order to test the susceptibility of triploids to different micro-organisms and to demonstrate that higher values of hemocyte parameters correspond to lower susceptibility to infectious diseases.

\section{Acknowledgements}

The authors would like to thank to Dr J.F. Samain (IFREMER, Brest, France) for managing the MOREST project group of research. Dr. P. Boudry and Dr. L. Degremont (Laboratory of Genetic and Pathology, La Tremblade, France) and the entire hatchery team (Laboratory of Genetic and Pathology, La Tremblade, France) are acknowledged for their contribution to oysters production. Dr. Philippe Goulletquer is acknowledged for his permission to perform these experiments in the laboratory. The authors also want to thank the Pr Susan Ford (Rutgers University, Port Norris, USA) for her reading and her helpful corrections of this paper. The study was partly financially supported by the Poitou-Charentes Region. 


\section{References}

Akashige, S., Fushimi, T., 1992. Growth, survival, and glycogen content of triploid Pacific oyster Crassostrea gigas in the waters of Hiroshima, Japan. Nippon Suisan Gakk. 58, 1063-1071.

Alcorn, S.W., Murra, A.L., Pascho, R.J., 2002. Effects of rearing temperature on immune functions in sockeye salmon (Oncorhynchus nerka). Fish Shellfish Immun. 12, 303-334.

Auffret, M., Mujdzic, N., Corporeau, C., Moraga, D., 2002. Xenobiotic-induced immunomodulation in the European flat oyster, Ostrea edulis. Mar. Environ. Res. 54, 585-589.

Barber, B.J., Mann, R., 1991. Sterile triploid Crassotrea virginica (Gemlin, 1791) grow faster than diploids but are equally susceptible to Perkinsus marinus. J. Shellfish Res. 10, 445-450.

Beattie, J.H., 1988. Summer mortality of Pacific oysters. American Fisheries Society Special Publication 18, 265-268.

Beaumont, A.R., Fairbrother, J.E., 1991. Ploidy manipulation in molluscan shellfish: a review. J. Shellfish Res. 10, 1-18.

Beckmann, N., Morse, M.P., Moore, C.M., 1992. Comparative study of phagocytosis in normal and diseased hemocytes of the bivalve mollusc Mya arenaria. J. Invertebr. Pathol. 59, 124-132.

Bligh, E.G., Dyer, W.J., 1959. A rapid method of total lipid extraction and purification. Can. J. Med. Sci. 37, 911-917.

Carballal, M.J., Lopez, C., Azevedo, C., Villalba, A., 1997. Enzymes involved in defense functions of hemocytes of Mussel Mytilus galloprovincialis. J. Invertebr. Pathol. 70, 96-105.

Cheney, D.P., Elston, R.A., Macdonald, B.F., 1998. Oyster summer mortality--an update on ongoing sea grant sponsored research. J. Shellfish Res. 17.

Cheney, D.P., MacDonald, B.F., Elston, R.A., 2000. Summer mortality of Pacific oysters, Crassostrea gigas (Thunberg): Initial findings on multiple environmental stressors in Puget Sound, Washington, 1998. J. Shellfish Res. 19, 353-359.

Cheney, D.P., Burnett, L.E., Christy, A., Davis, J.P., Elston, R.A., Friedman, C.S., Griffin, F., Langdon, C., Suhrbier, A., 2004. Improvement of disease resistance and understanding of summer mortality in Pacific oysters Crassostrea gigas. J. Shellfish Res. 23, 284-285.

Cheng, T.C., Lie, K.J., Heyneman, D., Richards, C.S., 1978. Elevation of aminopeptidase activity in Biomphalaria glabrata (Mollusca) parasitized by Echinostoma lindoense (Trematoda). J. Invertebr. Pathol. 31, 57-62.

Cheng, T.C., 1981. Bivalves. In: Ratcliffe, N.A., Rowley, A.F. (Eds.), Invertebrate Blood Cells I. Academic Press, London, pp. 233-299.

Cheng, T.C., 1996. Hemocytes: forms and functions. In: Kennedy, V.S., Newell, R.I.E., Eble, F. (Eds.), The eastern oyster Crassostrea virginica. Maryland Sea Grant College, College Park, pp. 299333.

Deslous-Paoli, J.M., Heral, M., Berthome, J.P., Razet, D., Garnier, J., 1981. Natural reproduction of Crassotrea gigas (Thunberg) in Marennes-Oleron Basin in 1979 and 1981 : biochemical and energetic aspects. In: Maritimes, R.d.T.d.I.I.d.P. (Ed.). IFREMER, Nantes, pp. 319-327.

Fisher, S.W., 1986. Structure and functions of oyster hemocytes. In: Brehélin, M. (Ed.), Immunity in Invertebrates. Springer-Vrelag, Berlin Heidelberg, pp. 25-35.

Friedman, C.S., Cherr, G.N., Clegg, J.S., Hamdoun, A.H., Jacobsen, J.L., Jackson, S.A., Uhlinger, K.R., 1999. Investigation of the stress response, summer mortality and disease resistance of oysters, Crassostrea spp. National Shellfisheries Association.

Garnier-Gere, P.H., Naciri-Graven, Y., Bougrier, S., Magoulas, A., Heral, M., Kotoulas, G., Hawkins, A., Gerard, A., 2002. Influences of triploïdy, parentage and genetic diversity on growth of the Pacific oyster Crassostrea gigas reared in contrasting natural environments. Mol. Ecol. 11, 1499-1514.

Glude, J.B., 1974. A summary report of Pacific Coast oyster mortality investigations 1965-1972, October $15-16^{\text {th }}$ 1974. Proceedings of the Third U.S.-Japan Meeting on Aquaculture, Tokyo, pp. 28.

Goedken, M., De Guise, S., 2004. Flow cytometry as a tool to quantify oyster defence mechanisms. Fish Shellfish Immun. 16, 539-552.

Goulletquer, P., Soletchnik, P., Le Moine, O., Razet, D., Geairon, P., Faury, N., Taillade, S., 1998. Summer mortality of the Pacific cupped oyster Crassostrea gigas in the Bay of MarennesOleron (France). ICES Mariculture Committee CM, Copenhagen, 14-21 pp.

Hand, R.E., Nell, J.A., Smith, I.R., Maguire, G.B., 1998. Studies on triploid oysters in Australia. XI. Survival of diploid and triploi Sydney Rock oysters (Saccostrea commercialis (Iredale and Roughley)) through outbreaks of winter mortality caused by Mikrocytos roughleyi infestation. J. Shellfish Res. 17, 1129-1135. 
Harris-Young, L., Tamplin, M.L., Mason, J.W., Aldrich, H.C., Jackson, J.K., 1995. Viability of Vibrio vulnificus in association with hemocytes of the American oyster (Crassostrea virginica). Appl. Environ. Microbiol. 61, 52-57.

Hawkins, A.J., Magoulas, A., Heral, M., Bougrier, S., Naciri-Graven, Y., Day, A.J., Kotoulas, G., 2000. Separate effects of triploidy, parentage and genomic diversity upon feeding behaviour, metabolic efficiency and net energy balance in the Pacific oyster Crassostrea gigas. Genet. Res. 76, 273-284.

Imai, T., Numachi, K.-i., Oizumi, J., Sato, S., 1965. Studies on the mass mortality of the oyster in Matsushima Bay II. Search for the cause of mass mortality and the possibility to prevent it by transplantation experiment. Bulletin of the Tohoku National Fisheries Research Institute 25, 27-38.

Koganezawa, A., 1974. Present status of studies on the mass mortality of cultured oysters in Japan and its prevention, Tokyo, pp. 29-34.

Lacoste, A., De Cian, M.C., Cueff, A., Poulet, S.A., 2001a. Noradrenaline and alpha -adrenergic signaling induce the hsp70 gene promoter in mollusc immune cells. J. Cell Sci. 114, 35573564.

Lacoste, A., Jalabert, F., Malham, S., Cueff, A., Gelebart, F., Cordevant, C., Lange, M., Poulet, S.A., 2001b. A Vibrio splendidus strain is associated with summer mortality of juvenile oysters Crassostrea gigas in the Bay of Morlaix (North Brittany, France). Dis. Aquat. Org. 46, 139-145.

Lacoste, A., Malham, S.K., Gelebart, F., Cueff, A., Poulet, S.A., 2002. Stress-induced immune changes in the oyster Crassostrea gigas. Dev. Comp. Immunol. 26, 1-9.

Le Roux, F., Gay, M., Lambert, C., Waechter, M., Poubalanne, S., Chollet, B., Nicolas, J.L., Berthe, F., 2002. Comparative analysis of Vibrio splendidus related strains isolated during Crassostrea gigas mortality events. Aquat. Living Resour. 15, 251-258.

Lodato, M.I., 1997. Mortalité estivale de l'huître creuse, Crassostrea gigas, sur les bancs ostréicoles de Perquis et Ronce (bassin de Marennes-Oléron): étude des pratiques culturales et des caractéristiques biologiques et spatiales des élevages, Ecole Nationale Vétérinaire, Nantes, pp. 127.

Magoulas, A., Kotoulas, G., Gerard, A., Naciri-Graven, Y., Dermitzakis, E., Hawkins, A.J.S., 2000. Comparison of genetic variability and parentage in different ploïdy classes of the Japanese oyster Crassostrea gigas. Genet. Res. 76, 261-272.

Marsh, J.B., Weinstein, D.B., 1966. Simple charring method for determination of lipids. J. Lipid Res. 7 , 574-576.

Matthiessen, G.C., Davis, J.P., 1992. Observations on growth rate and resistance to MSX (Haplosporidium nelsoni) among diploid and triploid eastern oysters (Crassostrea virginica (Gmelin, 1797)) in New England. J. Shellfish Res. 11, 449-454.

Meyers, J.A., Burreson, E.M., Barber, B.J., Mann, R., 1991. Susceptibility of diploïd and triploïd oysters, Crassostrea gigas, to Perkinsus marinus. J. Shellfish Res. 10, 304.

Mori, K., 1979. Effects of artificial eutrophication on the metabolism of the Japanese oyster Crassostrea gigas. Mar. Biol. 53, 361-369.

Nell, J.A., 2002. Farming triploid oysters. Aquaculture 210, 69-88.

Nell, J.A., Perkins, B., 2005. Studies on triploid oysters in Australia: farming potential of all-triploid Pacific oysters, Crassostrea gigas (Thunberg), in Port Stephens, New South Wales, Australia. Aquac. Res. 6, 530-536.

Perdue, J.A., Beattie, J.H., Chew, K.K., 1981. Some relationships between gametogenic cycle and summer mortality phenomenon in the Pacific oyster (Crassostrea gigas) in Washington State. J. Shellfish Res. 1, 9-16.

Renault, T., Le Deuff, R.M., Cochennec, N., Maffrat, P., 1994. Herpesviruses associated with mortalities among Pacific oyster, Crassostrea gigas, in France - comparative study. Rev. Méd. Vét. 145, 735-742.

Renault, T., Le Deuff, R.M., Cochennec, N., Chollet, B., Maffart, P., 1995. Herpes-like viruses associated with high mortality levels in larvae and spat of Pacific oysters, Crassostrea gigas: A comparative study, the thermal effects on virus detection in hatchery-reared larvae, reproduction of the disease in axenic larvae. Vet. Res. 26, 539-543.

Renault, T., Xue, Q.G., Chilmonczyk, S., 2001. Flow cytometric analysis of European flat oyster, Ostrea edulis, haemocytes using a monoclonal antibody specific for granulocytes. Fish Shellfish Immun. 11, 269-274.

Smith, I.R., Nell, J.A., Adlard, R., 2000. The effect of growing level and growing method on winter mortality, Mikrocytos roughleyi, in diploid and triploid Sydney rock oysters, Saccostrea glomerata. Aquaculture 185, 197-205. 
Soletchnik, P., Razet, D., Geairon, P., Faury, N., Goulletquer, P., 1997. Ecophysiology of maturation and spawning in oyster (Crassostrea gigas): Metabolic (respiration) and feeding (clearance and absorption rates) responses at different maturation stages. Aquat. Living Resour. 10, 177185.

Soletchnik, P., Le Moine, O., Faury, N., Razet, D., Geairon, P., Goulletquer, P., Forest, G., 1998. Spring and summer mortalities of the Pacific cupped oyster Crassostrea gigas in the Marennes Oleron Bay: Pilot study from Ronce and Perquis leasing grounds. RI DRV RA RST, La Tremblade, $55 \mathrm{pp}$.

Soletchnik, P., Le Moine, O., Faury, N., Razet, D., Geairon, P., Goulletquer, P., 1999. Summer mortality of the oyster Crassostrea gigas in the Bay Marennes-Oleron: spatial variability of environnement and biology using a geographical information system (GIS). Aquat. Living Resour. 12, 131-143.

Soletchnik, P., Huvet, A., Le Moine, O., Razet, D., Geairon, P., Faury, N., Goulletquer, P., Boudry, P., 2002. A comparative field study of growth, survival and reproduction of Crassostrea gigas, $C$. angulata and their hybrids. Aquat. Living Resour. 15, 243-250.

Soletchnik, P., Ropert, M., Huvet, A., Moal, J., Degremont, L., Bedier, E., Bouget, J.F., Dubois, B., Martin, J.L., Enriquez Diaz, M., Faury, N., Le Moine, O., Renault, T., Gagnaire, B., Samain, J.F., 2003. Characterization of summer mortalities of $C$. gigas oyster in France in relation to environmental parameters. J. Shellfish Res. 22, 354-355.

Soletchnik, P., Lambert, C., Costil, K., 2005. Summer mortality of Crassostrea gigas (Thunberg) in relation to environmental rearing conditions. J. Shellfish Res. 24.

Waechter, M., Le Roux, F., Nicolas, J.L., Marissal, E., Berthe, F., 2002. Characterisation of Crassostrea gigas spat pathogenic bacteria. C. R. Biologies 325, 231-238.

Xue, Q.G., Renault, T., Chilmonczyk, S., 2001. Flow cytometric assessment of haemocyte subpopulations in the European flat oyster, Ostrea edulis, haemolymph. Fish Shellfish Immun. 11, 557-567. 
Table 1. Multi way analysis of variance of hemocyte parameters versus "level" (L1 $=15 \mathrm{~cm}$ and L2 = $70 \mathrm{~cm}$ ) and "group" ( $\mathrm{D}=$ diploids from natural bed, $\mathrm{Dh}=$ hatchery diploids and $\mathrm{T}=$ triploids). Significant effects are reported at $5 \%\left(^{(}\right), 1 \%\left(^{(\star}\right)$ and $1 \%\left(^{(* \star}\right)$ probability level. NS $=$ no significant difference. Related LSD (Least Significant Difference) post hoc tests are reported.

\begin{tabular}{|l|l|l|}
\hline Hemocytes activities & Level & Group \\
\hline Phagocytosis activity & $\mathrm{NS}$ & $\mathrm{T}>\mathrm{Dh}, \mathrm{D}$ \\
& $\mathrm{P}=0.3108$ & $\mathrm{P}<0.0001$ \\
Peroxidase activity & $\mathrm{NS}$ & $\mathrm{T}>\mathrm{D}>\mathrm{Dh}$ \\
Esterase activity & $\mathrm{P}=0.5192$ & $\mathrm{P}<0.0001$ \\
& $\mathrm{NS}$ & $\mathrm{T}>\mathrm{Dh}, \mathrm{D}$ \\
Granulocyte percentage & $\mathrm{P}=0.1680$ & $\mathrm{P}=0.0130$ \\
Hemocytes mortality & $\mathrm{NS}$ & $\mathrm{T}>\mathrm{Dh}, \mathrm{D}$ \\
& $\mathrm{P}=0.8780$ & $\mathrm{P}=0.0203$ \\
& $\mathrm{NS}$ & $\mathrm{NS}$ \\
\hline
\end{tabular}


Table 2. Multi way analysis of variance of hemocyte parameters versus "level" (L1 $=15 \mathrm{~cm}$ and L2 $=$ $70 \mathrm{~cm}$ ), "group" ( $\mathrm{D}=$ diploids from natural bed, $\mathrm{Dh}=$ hatchery diploids and $\mathrm{T}=$ triploids), and maturation stage (gametogenesis $=\mathrm{A}$, ripe gametes $=\mathrm{B}$, post spawning $=\mathrm{C}$ ). Significant effects are reported at $5 \%\left({ }^{*}\right), 1 \%\left(^{* *}\right)$ and $\left.1 \%{ }^{(* \star}\right)$ probability level. NS = no significant difference.

\begin{tabular}{|c|c|c|c|}
\hline Hemocytes activities & Level & Group & $\begin{array}{l}\text { Maturation } \\
\text { stage }\end{array}$ \\
\hline Phagocytosis activity & NS & $\underset{\star \star \star \star}{\mathrm{T}}>\mathrm{Dh}, \mathrm{D}$ & $\underset{* \star * *}{\mathrm{~A}<\mathrm{B}}$ \\
\hline Peroxidase activity & NS & $\mathrm{T}>\underset{\star \star \star}{\mathrm{D}}>\mathrm{Dh}$ & $\mathrm{A}<\underset{* \star \star}{\mathrm{B}<\mathrm{C}}$ \\
\hline Esterase activity & $\begin{array}{c}\mathrm{L} 1>\mathrm{L} 2 \\
*\end{array}$ & $\underset{* \star}{\mathrm{T}}>\underset{* \mathrm{Dh}}{\mathrm{D}} \mathrm{D}$ & $\underset{* \star *}{\mathrm{~A}<\mathrm{B}}<\mathrm{C}$ \\
\hline Granulocyte percentage & NS & $\underset{\star \star}{\mathrm{T}}>\underset{\mathrm{Dh}}{\mathrm{D}} \mathrm{D}$ & $\underset{* \star \star}{A}<$ B, C \\
\hline Hemocytes mortality & NS & NS & $\underset{\star \star \star \star}{\mathrm{A}}<\mathrm{B}, \mathrm{C}$ \\
\hline
\end{tabular}




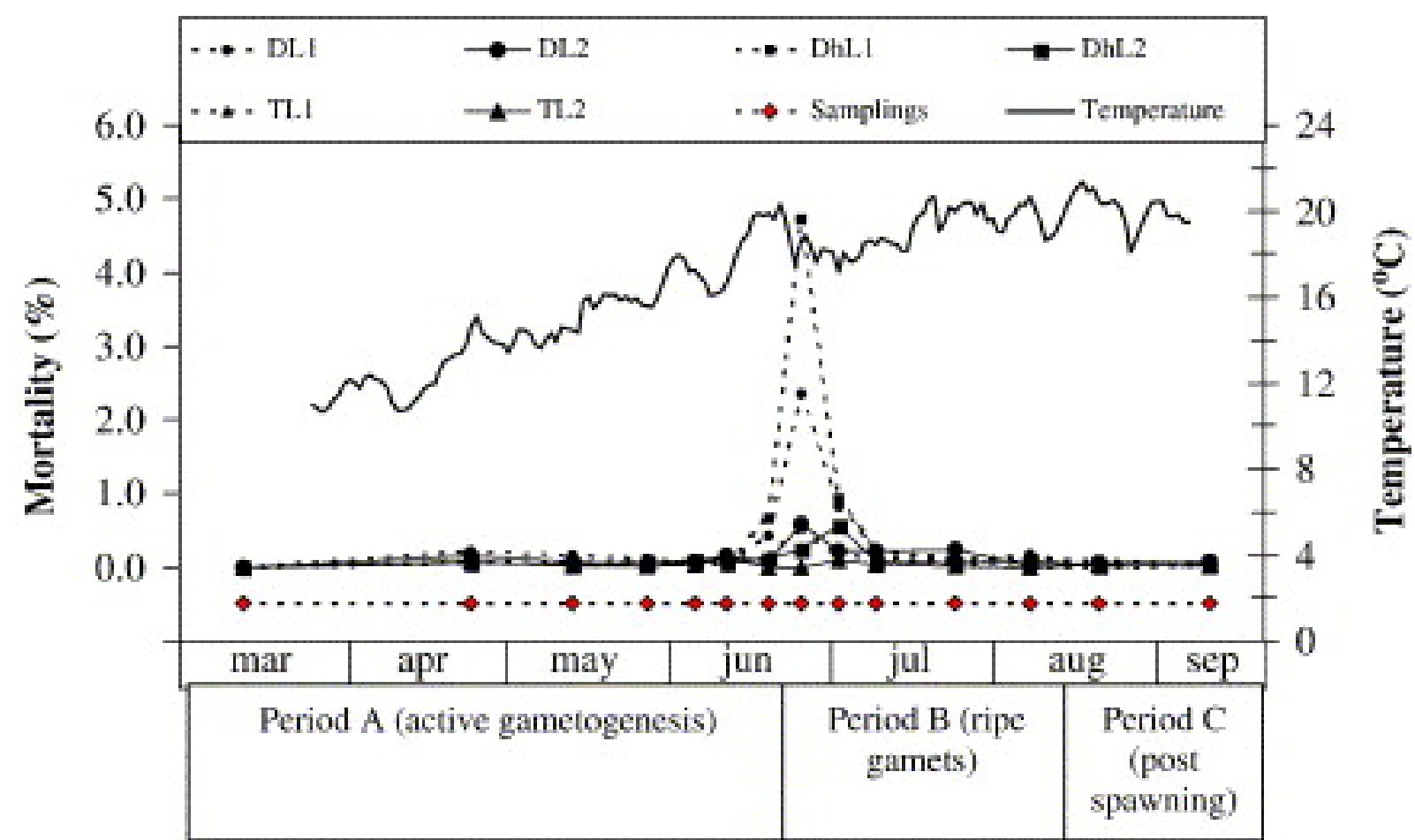

Figure 1. Daily mortality rate of oyster groups: wild diploid oysters (D), hatchery bred diploid (Dh) and triploid $(T)$ oysters reared on culture racks, L1 level $(15 \mathrm{~cm})$ or L2 level $(70 \mathrm{~cm})$ above the sediment.

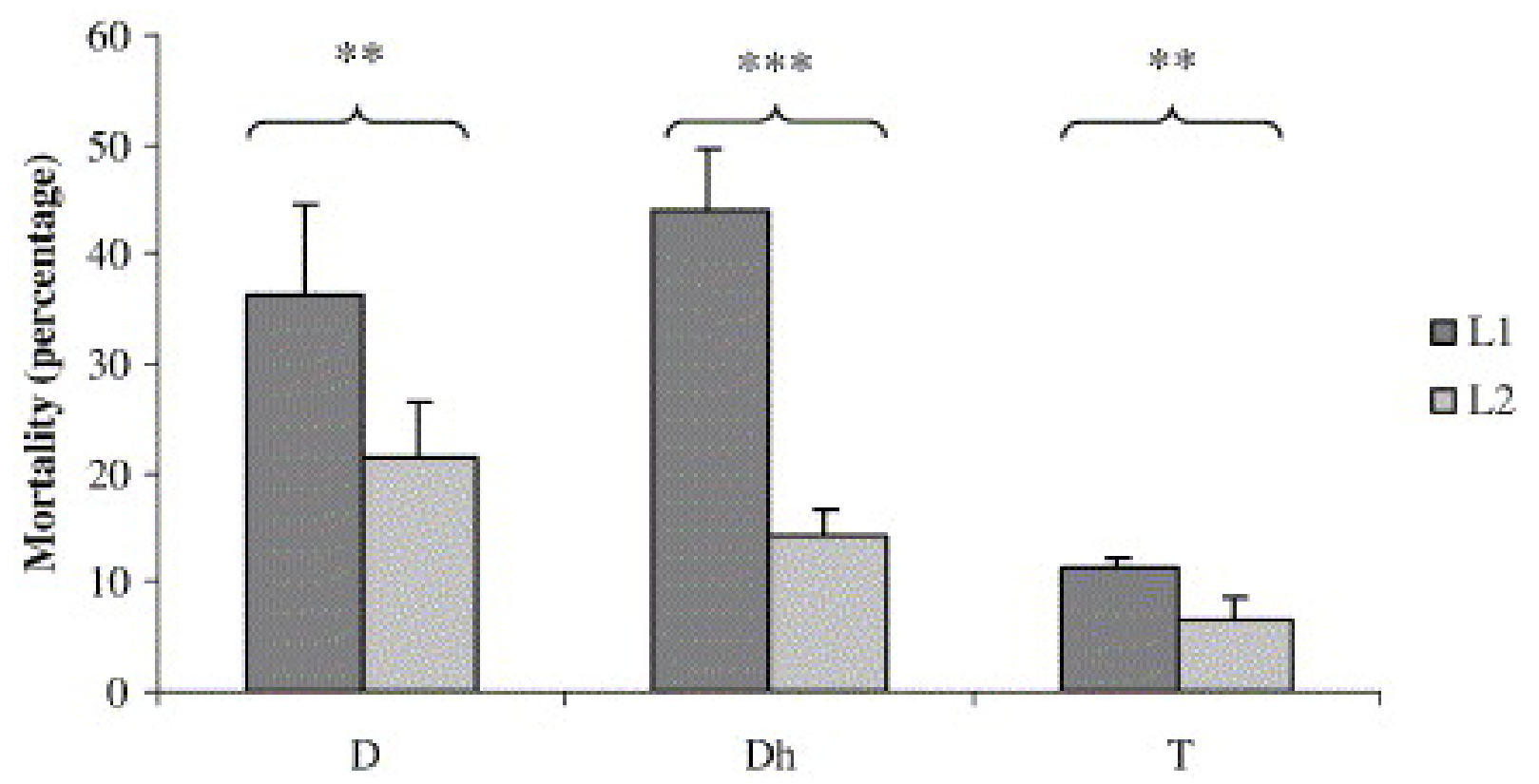

Figure 2. Cumulative mortality of wild oysters (D), hatchery diploids (Dh) and triploids (T) reared on culture racks at $15 \mathrm{~cm}$ (L1) or $70 \mathrm{~cm}$ (L2). Values are means of 3 replicates. Bars are confident limit at $95 \%$. The post-hoc test gives: TL2 < (TL1-DhL2) < (DhL2-DL2) < (DL1-DhL1). ${ }^{* *: ~ p<0.01 ; ~}{ }^{* \star *}$ : $\mathrm{p}<0.001$. 

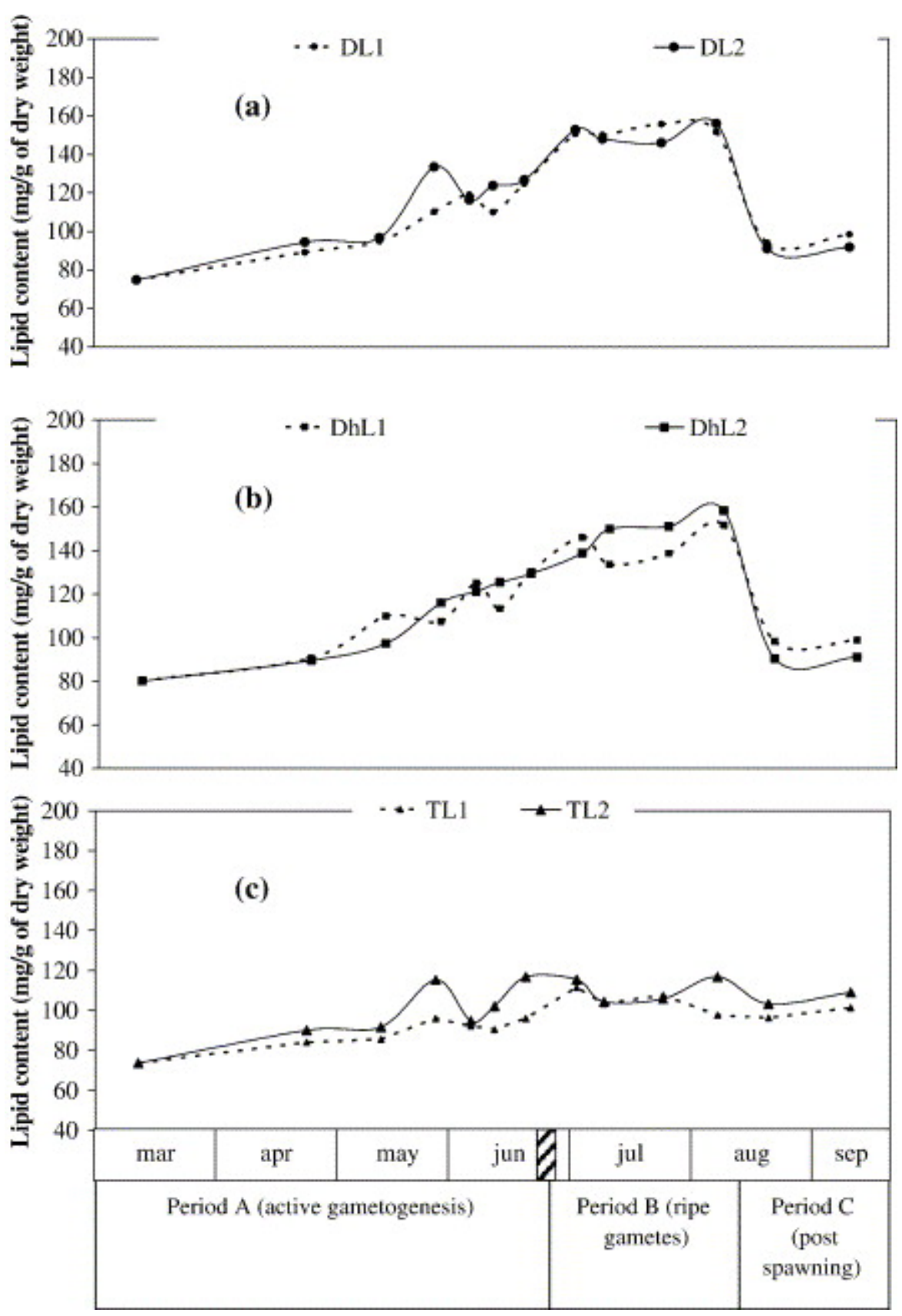

Figure 3. Lipid content ( $\left.\mathrm{mg} \mathrm{g}^{-1}\right)$ in the dry flesh along the experiment for wild diploids (D) (a), hatchery bred diploids (Dh) (b) and triploids $(\mathrm{T})(\mathrm{c}) \mathrm{c}$ reared at $\mathrm{L} 1$ and $\mathrm{L} 2$. Values are means of three replicates of ten oysters. Hatched surface indicates the mortality period. 

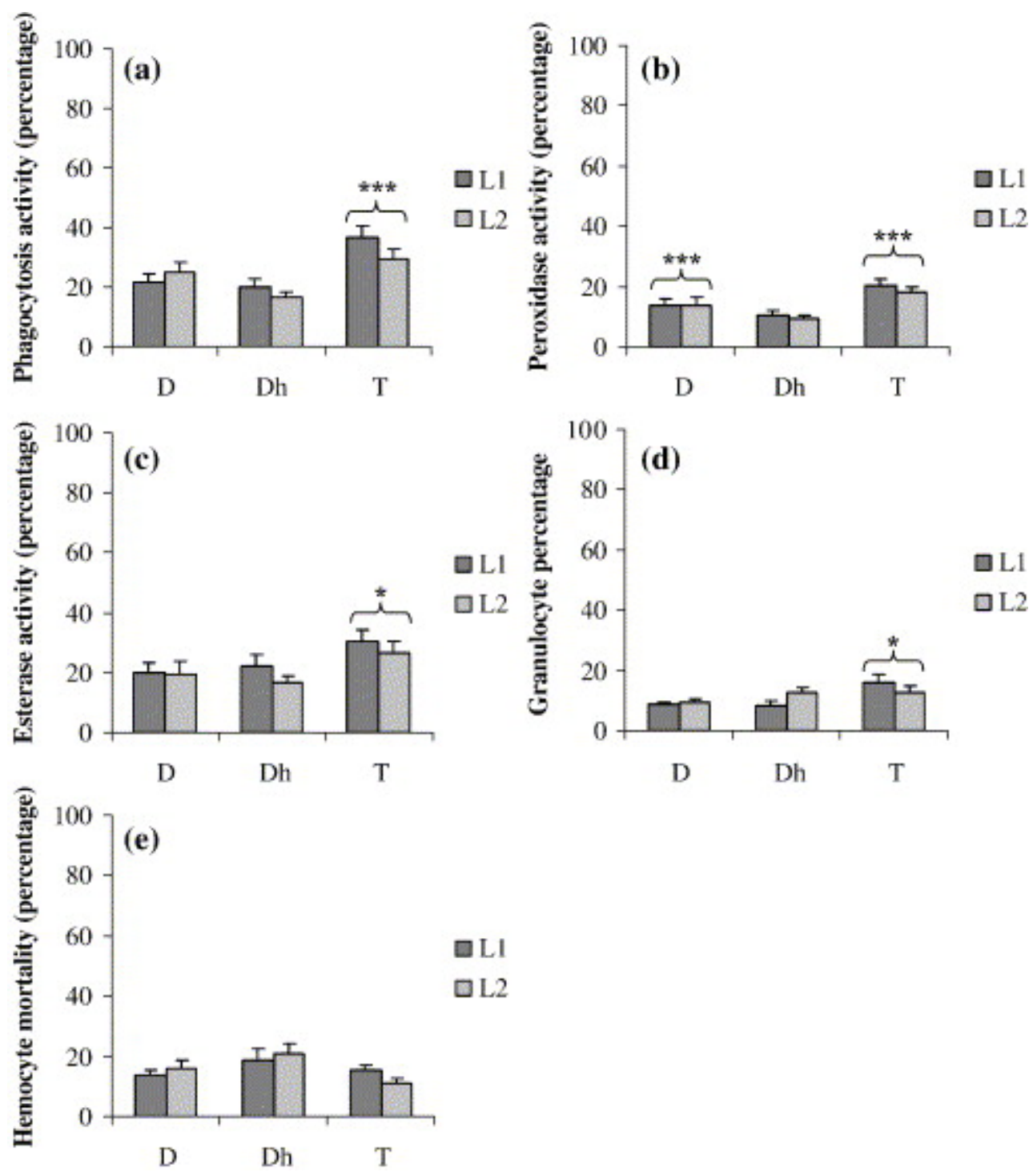

Figure 4. Means and standard errors of the means of hemocyte parameters for the three oyster groups $(\mathrm{D}=$ diploids from natural bed, $\mathrm{Dh}=$ hatchery diploids and $\mathrm{T}=$ triploids $)$ and both distances above sediment $(\mathrm{L} 1=15 \mathrm{~cm}, \mathrm{~L} 2=70 \mathrm{~cm})$. a: percentage of cells that phagocytosed beads in vitro; $\mathrm{b}$ : percentage of cells presenting a peroxidase activity; c: percentage of cells presenting an esterase activity; d: granulocyte percentage; e: hemocyte mortality. Significant differences between groups are indicated with stars : ${ }^{*}=p<0.05 ;{ }^{* \star *}=p<0.001$. 

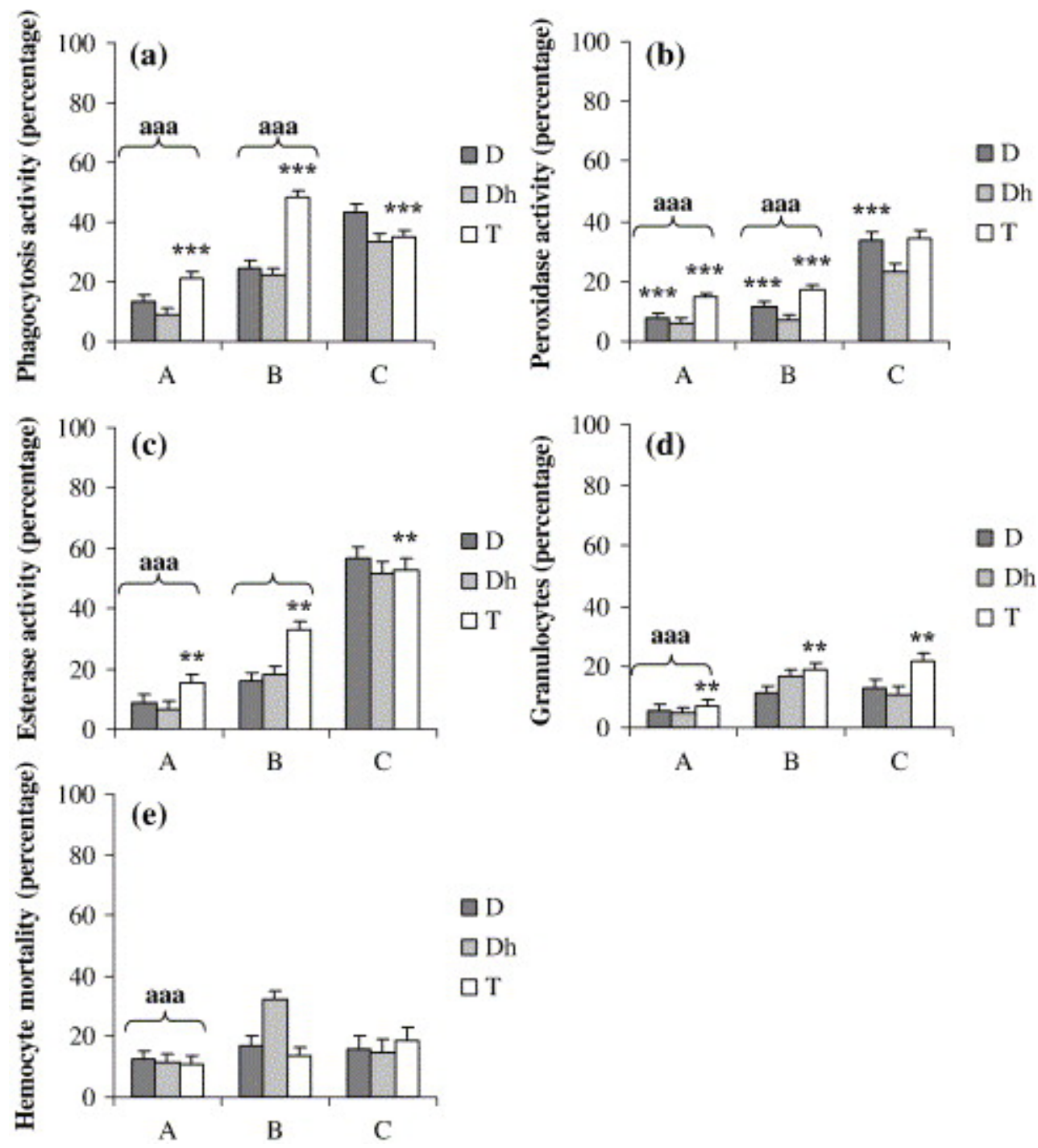

Figure 5. Means and standard errors of the means of hemocyte parameters over the three periods (A = gametogenesis, $\mathrm{B}=$ ripe gametes and $\mathrm{C}=$ post-spawning) for the three oyster groups $(\mathrm{D}=$ diploids from natural bed, $\mathrm{Dh}=$ hatchery diploids and $\mathrm{T}=$ triploids). a: percentage of cells that phagocytosed beads in vitro; $b$ : percentage of cells presenting a peroxidase activity; $c$ : percentage of cells presenting an esterase activity; d: granulocyte percentage; e: hemocyte mortality. Significant differences between

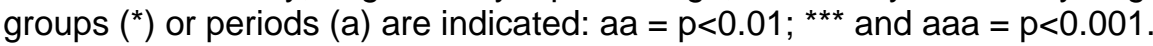

